\title{
THE BRAND NEW TESTAMENT'TA ALTERNATİF BİR DÜNYA KURGUSU: BABALIK KRİZİ VE ANAERKİL ÜTOPYA
}

\author{
Emek Çaylı Rahte \\ Hacettepe Üniversitesi İletişim Fakültesi
}

\begin{abstract}
Öz
Dinsel filmler, bir yanıyla dinin sinemayı kolonileştirmesini, diğer yanıyla ise kutsal olanın eleştirel bakışa konu edilmesini örnekler. Dinsel olanı ve ilahi alanı mizah konusu yapan filmlerde, inancı merkeze alan bir yaşam tasavvuru ile gündelik hayatı şekillendiren ilahi yasaların ve dini figürlerin hicvedildiği bir anlatısallık bir aradadır. Dinsel komedinin, türüne az rastlanan bir örneği olan, Jaco Van Dormael'in yönettiği The Brand New Testament (Le Tout Nouveau Testament / Yeni Ahit, 2015), Tanrı'nın insan imgesinde mizah unsuru haline geldiği, ütopik bir anlatımla ataerkil dünya eleştirisi getiren bir politik komedi filmidir. Anaerkil bir toplum düşü kuran film, bu çalışmada, eril yasalara itirazın dinsel komedi ile nasıl mümkün olduğu temel sorusu bağlamında ve feminist perspektifle incelenmektedir. Çalışmada, sinemada din olgusuna yaklaşımlara yer verilmekte, din ve mizah ilişkisi ele alınmakta ve dilsel ve görsel mizahta Tanrı figürüne dair tarihsel arka plan bilgisi sunulmaktadır. Film üzerine çözümlemeler, babalık krizi ve babasız topluma ilişkin filmin öngörüleri ve alternatif bir dünya kurgusu olarak sunulan anaerkil yeni dünya tahayyülü etrafında örülmektedir.
\end{abstract}

Anahtar Sözcükler: The Brand New Testament, dinsel komedi, Tanrı imgesi, mizah, anaerkil toplum.

Bu çalışma 12 Temmuz 2018 tarihinde sinecine dergisine ulaşmış;

30 Ağustos 2018 tarihinde kabul almıştır. 


\title{
The Fiction of an Alternative World in The Brand New Testament: The Fatherhood Crisis and Matriarchal Utopia
}

\begin{abstract}
Religious films exemplify the colonization of cinema and offer a critical view of the holy figures. In movies that make the religious and divine into subjects of humor, an imagined belief-centered life is combined with a narrative in which the divine laws shaping everyday life and religious figures are satirized. The Brand New Testament (Le Tout Nouveau Testament, 2015), a rare example of religious comedy, is also a political comedy. It is a dystopian narrative criticizing the patriarchal world in which God, in human form, is a comic figure. From a feminist perspective, the study analyzes how the film, which imagines a matriarchal society, raises objections to the rule of masculine law through religious comedy. Approaches to religion in cinema are considered. The relationship between religion and humor is discussed, along with the historical background of a God figure in verbal and visual humor. The analysis is focused on the crisis of fatherhood, the film's vision of a fatherless society, and the imagined matriarchal new world that is presented here as an alternative to the patriarchal world.
\end{abstract}

Keywords: The Brand New Testament, religious comedy, image of God, humor, matriarchal society. 


\section{Giriş}

Yaygın kanıya göre birbiri ile bağdaştırılamaz kabul edilen din ve mizah, birbirinden beslenen ve hatta birbirine gereksinim duyan iki farklı alan olarak da okunmaktadır. Kutsal değerlere hakaret ve dini duyguları rencide etmek gibi "kırmızı çizgiyi" ihlal suçlamalarıyla sıkça karşılaşan dinsel mizahın, sözel ifade biçimlerinin yanı sıra resim, karikatür, film ve animasyon formlarında görsel örneklerine de rastlanmaktadır. Hollywood ve Avrupa sinemasının başını çektiği "dinsel komedi" türü içerisinde sınıflandırılan filmler, dinsel mizahın kitleselleşmesinde pay sahibidir. ${ }^{1}$ Politik mizahın bir unsuru olarak görülebilecek dinsel mizahın yaygın örneklerinde din adamlarına eleştirel yaklaşım ağırlık kazanır. Tanrı ve peygamberlerin görsel temsilleri ve mizah yoluyla hicvedilmeleri ise dinsel mizahın bir başka kritik noktasını oluşturur.

Bu çalışmada, az rastlanan dinsel-komedi türünün bir örneği olan, Belçikalı yönetmen Jaco Van Dormael'in 2015 tarihli The Brand New Testament / Le Tout Nouveau Testament / Yeni Ahit ${ }^{2}$ filmi din, mizah ve sinemaya dair bir tartışma üzerinden, dinsel mizah yoluyla toplumsal ve siyasal eleştiri çerçevesinde ele alınmaktadır. Semavi dinlerde Tanrı'nın ve peygamberlerin resmedilmesi ve/veya nasıl imgeselleştirileceği konusu ihtilaflar yaratan, kutsal olanın dokunulmazlık talebi gibi nedenlerle tartışmalı bir mesele olagelmiştir. ${ }^{3}$ Bunu mizahın diliyle gerçekleştir-

1 Türün klasiklerinden olan Monty Phyton serisinin yanı sıra önde gelen diğer örnekler: Simon of the Desert (Luis Bunuel, 1965), Dogma (Kevin Smith, 1999), Bruce Almighty (Aman Tanrm, Tom Shadyac, 2003), Adam's Apple (Anders Thomas Jensen, 2005), Religulous (Larry Charles, 2008), Where Do We Go Now? (Nadine Labaki, 2011) ve We Have a Pope (Nanni Moretti, 2011).

2 Orijinal adı Le Tout Nouveau Testament olan film Belçika, Fransa ve Lüksemburg ortak yapımıdır. 2016'da Yabancı Dilde En İyi Film dalında Altın Küre ödülüne aday gösterilmiştir. Çeşitli film festivallerinde 11 ödül kazanmıştır. Ödül detayları için bkz. https:// www.imdb.com/title/tt3792960/awards?ref_=tt_awd. Yeni Ahit olan Türkçe çevirisi, filmin orijinal adını ve mizahi tonunu yansıtmamaktadır. Kutsal kitabın ismini olduğu gibi kullanan bir isim yerine "En Yeni Ahit" gibi bir çeviri benimsenmesinin daha yerinde olacağı düşünüldüğünden, İngilizce ismi ile tanınırlığı da göz önünde bulundurularak makalede filmin İngilizce adı kullanılmaktadır.

3 Hz. Muhammed'in tasvirinin tarihsel izleği için Wijdan Ali'nin 2001'de yazdığı "From 
mesi, hassas bir zeminde söz söyleyen ve ataerkinin dinsel olanla bağını komedi aracılığıyla kuran The Brand New Testament filmini incelemeyi önemli kllmaktadır. The Brand New Testament kötücül Tanrı Baba, onun otoritesini alaşağı eden on yaşındaki kızı $\mathrm{Ea}^{4}$, bir heykel olarak hayatını sürdüren ağabeyi $\mathrm{JC}^{5}$ ve Tanrı'nın dünyayı yönettiği bilgisayarın başına tesadüfen oturup dünyayı değiştiren, önce sıradan ev kadını, sonra ise dünyanın yeni yöneticisi Tanrıça-Anne'nin hikâyesidir. Bu hikâye örgüsünden hareketle, Tanrı figürünün komedi unsuru olarak kullanılmasının tarihsel arka planını sunarak, sinema özelinde "Tanrı'ya gülmek" meselesine dair bir değerlendirme yapmak amaçlanmaktadır. Makalede dinsel komedinin, inançtan uzak bir dünya tasavvuru sunmaktan oldukça uzakta, bilakis inancı merkeze alan ve onu olumlayan bir anlatısallığı olduğu savından hareket edilmektedir. Dinsel metinler yaratılış hikâyeleri ve toplumsal yaşam ve dünyanın gerçekliği hakkında anlattıkları öyküler ve mitoslar ile toplumsal cinsiyet rollerine dair de söz söylerler. Dini temalı filmlerde yaratılan imge ve anlamların, toplumsal cinsiyet ilişkilerini kapsayan ideoloji ve pratiklere dair izler taşıması dünyevi ve ilahi alanın birbiriyle yakın teması ile oldukça bağlantılıdır. Bu çalışmada, söz konusu bağlantının komedi türünde nasıl tezahür ettiğine bakılmaktadir.

Ridley Scott'un Exodus: Gods and Kings (2014) filminde Malak'in Tanrı'yı temsil eden bir karakter olması örneği bir yana, dinsel figürlerin imgeselleştirilmesinin yaygın olarak mizah yoluyla hayata geçtiğine işaret eden Reinhold Zwick Dogma, Bruce Almighty ve The Brand New Testament filmlerini örnek vererek, sinemada Tanrı'nın doğrudan temsillerinin daha çok, komedi üzerinden olduğuna değinir (2017, s. 134). ${ }^{6}$ Öte yandan dinsel komedi filmlerinin, komedi türü içerisinde sınırlı bir payı vardır.

the Literal to the Spiritual: The Development of the Prophet Muhammad's Portrayal from 13th Century Ilkhanid Minatures to 17th Century Ottoman Art" başlıklı makalesine bakılabilir.

4 Babilonya'lı bilgelik Tanrısı ve her türlü sihirin kaynağı Ea'ya bir göndermedir. Ea'nın Sümer versiyonundaki adı Enki'dir (Hooke, 2002).

5 İsa Peygamber'e ("Jesus Christ") göndermedir.

6 Doğrudan The Brand New Testament üzerine yapılmış bir akademik çalışmaya rastlanmamakla birlikte, Folklor/Edebiyat Dergisi'nde Medya Tanıtım bölümünde filme dair kısa bir değiniye ulaşılmıştır. Bu değinide yazar, filmde yer aldığını varsaydığı "her şey insanın elinde" düşüncesinin, dünyayı yeniden yaratmada "kadın elinin" değmesiyle yeniden pekiştirildiğini dile getirir (Karatekin, 2016, s. 283-285). 
Sinema ve din ilişkisine yönelik akademik ilgiye tezat oluşturacak şekilde, sinemada dinsel komedi konusuna dair literatür oldukça sınırlıdır. Bunda şüphesiz toplumsal, kültürel hassasiyetler ve dinsel konuların mizah bağlamında işlenmesi önündeki tabular ve bununla ilişkili olarak dinsel komedi türünde filmlerin, komedi türü içerisinde görece az sayıda olmasının da payı vardır. Dilsel mizah ile görsel mizah, dinsel etkilerle farklı kültürlerde farklı biçimlerde gelişme göstermiştir. Resim ve heykel sorunu İslam kültüründe görsel ifadenin gelişimine ket vurmuştur. Bununla bağlantılı olarak, form bozmaya dayalı görsel mizahtan uzak kalınması, İslam kültüründe dinsel olanın mizah konusu edilmesini dile dayalı hiciv geleneği ile sınırlandırmıştır. Deyimler, flkralar ve hicivler gibi dilsel nüktedanlıklar taşıyan kalıplar biçiminde gelişen İslam mizahı, görsel ifade bakımından İslami mizah dergileri ile gelişim göstermiştir (Çolak, 2016, s. 232-233). Dolayısıyla, din ve mizah konusunda Türkiye'de yapılan çalışmaların, oldukça az sayıda olmakla birlikte, fikraları, mizah dergilerini ve İslami mizahın gelişimini konu edindiği görülmektedir.7 Sinemada dinsel mizaha kısaca temas eden birkaç çalışmada ise, dinin mizah malzemesi yapılmasına yönelik eleştirel bakış ağırlık kazanmaktadır. Örneğin Asife Ünal, "Uyumlu Bir Dünya İnşası Bağlamında Sinema ve Din İlişkisi: 'Life of Pi' Örneği" makalesinde dinsel mizah alanının önde gelen filmlerinden ${ }^{8}$ dinlere veya din olgusuna olumsuz bakan, dinleri hicveden filmler olarak söz eder (2015, s. 572). "Kertenkele'nin Serencamı: Bir Film Üç Algı" adlı yazısında Bilal Toprak ise, "Hollywood, İran ve Yeşilçam sinema geleneklerinin din adamını ele alış biçimlerini ve bir filmi kendi geleneklerine dönüştürmedeki başarılarını veya başarısızlıklarını" konu alır (2015, s. 522). Makalede Toprak, dinsel alanda yerleşikleşmiş yanlış kabullerin mizah unsuru ile eleştirilmesinin olanaklılığını da irdeler.

Dinsel komediye ilginin bu denli sinırlı olduğu bir akademik iklimde bu çalışma, Tanrı'nın görselleştirildiği ve dinsel figürlerin dünyevileştirildiği bir komedi filmini, dinsel komedi yoluyla toplumsal-siyasal

7 Bu çalışmalar şunlardır: Cantek, L. \& Gönenç, L. (2011). Türkiye'de İslami Mizahın Yükselişi. Birikim, 268-269, 49-65; Koçak, S. (2012). Türkiłe'de İslamcı Mizah Dergiciliği: Cafcaf Dergisi Örneği. (Yayımlanmamış Yüksek Lisans Tezi). Hacettepe Üniversitesi Sosyal Bilimler Enstitüsü, Ankara; Marzolph, U. (2000). The Qoran and Jocular Literature. Arabica, 47, 478-487; Altınay, R. (2004). İslam Mizahının Ortaya Çıkışı ve İlk Örnekleri. Nüsha, 4(15), 77-96.

8 Life of Brian (Brian'in Hayatı, Terry Jones, 1979), Dogma, The Invention of Lying (Yalanin İcadl, Ricky Gervais, Matthew Robinson, 2009) ve Religulous (İlahi Komedi) filmlerini örnek verir. 
eleştiri bağlamında tartışarak önemli bir boşluğu bir nebze olsun doldurmayı arzu etmektedir. Eril yasalarla işleyen dünya kurgusunun filmde nasıl hicvedildiği temel sorusu üzerinden, patriyarka kuramı, kültürel feminist teori, ebeveynliğin ve ailenin psikanalitik ve politik analizi gibi geniş bir çerçeveden kurulan filme dair çözümlemeler, babalık krizi ve babasiz dünyaya dair filmin öngörüleri ve alternatif bir dünya kurgusu olarak sunulan anaerkil yeni dünya tahayyülü etrafında örülmektedir.

\section{Sinema ve Din}

Film, izleyici ve endüstri bağlamında bir bütün olarak sinemanın, dinsel olanla her zaman bağı olmuştur. Sinemanın en erken dönemlerinden itibaren dinsel temalar filmlerin önemli bir bileşenidir. Bu konuda başı çeken Amerika'da 1960'lara kadar Katolik kilisesinin ve dini örgütlerin sinema endüstrisi üzerinde ciddi bir baskı unsuru oluşturmaları nedeniyle belli kodların dışına çıkan filmlerin, dini çevrelerin etkisini görece yitirdiği 70'lerden sonra artışa geçtiğinden söz edilmektedir (Williams, 2000). Dinsel otoriteler için sinema aynı zamanda dinsel alanın kendini ifade etme aracı olması açısından da her daim önemsenen bir mecradır. Nihayetinde film, farkl dini toplulukların kendilerini ifade etme ya da temsil edilme aracı olduğu kadar aynı zamanda dinin rolünün ve anlamının da tartışılabildiği bir mecra sunmaktadır.

Dinsel temalara yer veren azımsanmayacak sayıda güncel film, bir yanıyla dinin sinemayı kolonileştirmesini, diğer yanıyla ise kutsal olanın eleştirel bakışa konu edinmesini örneklemiştir. Melanie J. Wright (2007) dünya çapında izleyici kitlesine ulaşan The Chronicles of Narnia (Narnina Günlükleri, Andrew Adamson, 2005) ve The DaVinci Code (DaVinci Şifresi, Ron Howard, 2006) gibi örneklere yer vererek, Hollywood ve Avrupa sineması başta olmak üzere, dinsel filmlerin bir yandan büyük bir pazara sahipken bir yandan da dindar çevrelerin tepkilerini üzerlerine çekmek gibi bir ünleri olduğundan söz eder. Din ve sinema ilişkisinin bu ikircikli hali, filmlerin dinsel konulara yer veriş biçimleri için de söz konusudur. Doğrudan ya da dolaylı yollarla dinsel içerikleri olan kimi filmlerde dini hassasiyetleri besleyen, propaganda nitelikli anlatılar hâkimken (örneğin The Miracle Maker, Hayes \& Sokolov, 2000) kimileri de alternatif yorumlar, dinsel özeleştiriler sunan nitelikleriyle (örneğin The Name of the Rose / Gülün Adr, Jean Jacques Annaud, 1986; Goya's Ghosts / Goya'nın Hayaletleri, Milos Forman, 2006) tartışmalar yaratmıştır. Sinema ve din ilişkisinin karmaşıklığı izleyicinin bu filmlerle nasıl bir ilişki kurduğu ve dinsel 
içerikleri nasıl alımladığı meselesini de kapsamaktadır; dinsel filmlerin alımlanmasına dair çalışmalara çok az rastlansa da. ${ }^{9}$

Filmin kendisinin modern ya da post-modern toplumun dini olduğu görüşüne yaslanan bakış açılarına göre film, ortak değerlerin, rollerin ve ihtilafların dile getirilmesine imkân yaratarak anlaşmazlıkları idare eder, toplumsal birliği ve kolektiviteyi destekler (Wright, 2007, s. 14). Dinin edebiyat ve sinema ile bağının, bir anlatı üretme mekanizması olması ile de ilişkili olduğunu dile getiren Wright, din ve filmin ilişkisini kurarken her ikisinin de insanın duygu ve düşüncelerini metaforlarla ve sembollerle ifade etme ihtiyacının bir ürünü olduğuna dikkat çeker. Din ve film imgelerin, sözün ve fikrin gücünü kullanarak insanı bilinmez, görünmez ve tarif edilemeze yaklaştırır (Wright, 2007, s. 4). Hristiyan teolojisi alanında din ve filme dair çalışmaların oldukça araçsalcı ve pragmatik olduğunu savunan Wright, dinsel araştırmalar alanının film çalışmalarına teolojiye göre daha zengin bir katkısı olduğuna inanır. Teolojik perspektifte, filmler aracilığıyla seküler kültürün dinin geleneklerine meydan okuyan tavrına bir yanıt verme temel amacı söz konusudur. Dinsel araştırmalar ise, belli bir inanca odaklanmak yerine dinlerin tüm insanlık ve toplumlar için var olan bir öğreti olduğu savından hareket eder. Film ve din ilişkisine bakışları da buradan beslenir (Wright, 2007, s. 5). Öte yandan Wright, esasında en az örneğine rastlananın eleştirel perspektifli çalışmalar olduğu görüşündedir. Din ve film alanındaki çalışmaların pek azı sinema ve film çalışmalarına eleştirel yaklaşımlardan haberdardır. Türkiye'de de durum çok farklı değildir.

Türkiye'de sinema ve din konusuna ilgide artış, yaklaşık olarak son 10 yıllık bir süreci kapsamaktadır. ${ }^{10}$ Esasında Türkiye'de ağırlıklı olarak ilahiyat alanından akademisyenlerce bu konuda çalışmalar yapıldığı gözlenmektedir. Bu da üretilen çalışmalarda İslam teolojisi çerçevesinin hâkim olmasını beraberinde getirmiştir. Sinema ve din konusuna Türk sinemasının tarihsel izleği, türsel sinıflandırmalar ve dönem filmleri bağlamında temas edilmişse de ${ }^{11}$ doğrudan din ve sinema ilişkisini me-

9 Bir alımlama çalışması örneği için bkz: Lyden, J. (2015). Film. C. J. Lyden \& E. M. Mazur (Eds.), The Routledge Companion to Religion and Popular Culture (s. 80-100). New York: Routledge.

102002 yllından bu yana süregelen AKP iktidarının bunda etkisi ve bu konuya yönelmeye katkısı şüphesizdir.

11 Bkz: Özön, N. (1995). Karagözden Sinemaya Türk Sineması ve Sorunlarl. 2. Cilt. Ankara: Kitle; Kayalı, K. (1988). Türk Sinemasına Hafızasını Kazandırmak Gerek. Bilim 
sele edinen çalışmalar son yıllarda hız kazanmıştır. ${ }^{12}$ Türkiye'de bu konudaki güncel tartışmaların ekseni $A B D$ ve Avrupa kaynaklı filmlerdeki açık ya da örtük dini propaganda teması ve Türk sinemasında benzeri şekilde bir İslam dini bilgisinin filmlere gereğince konu edilmeyişi, konu edildiğinde ise temsil sorunlarının merkezde olduğu eleştirisi üzerinden çizilmektedir. ${ }^{13}$ Çalışmalarda Türkiye'de dini sinemanın ${ }^{14}$ koşulları da ele alınmaktadır. İbrahim Yenen "Toplumsal Tezahürleri Bağlamında Türk Sinemasında Din, Dindarlık ve Din Adamı Olgusu" (2011) adlı doktora tezinde hem bu meselelere temas eder hem de dinin ticari amaçlarla kullanılması sorununa eğilir. Sinemada din konusunu tüm dinlere eşit mesafede yaklaştığını düşündüğü Pi'nin Yaşamı filmi üzerinden ele alan Asife Ünal (2015) farklı dinlerin konu edildiği filmlerin bir derleme-

ve Sanat, 87, s. 12-15; Scognamillo, G. (1998). Türk Sinema Tarihi. 3. Baskı. İstanbul: Kabalcı; Arslan, S. (2006). Yeşilçam'ın Yeşil Yüzü: Memleketim. D. Bayrakdar (Haz.), Türk Film Araştırmalarında Yeni Yönelimler- 5 (s. 185-196). İstanbul: Bağlam; Özgüç, A. (1993). 100 Filmde Başlangıcından Günümüze Türk Sineması. İstanbul: Bilgi.

12 Önemli bir erken dönem çalışması Türkiye dışından, çalışmalarını yurt dışında yürüten ve Women, Islam and Cinema adlı kitabı (2004) kaleme alan Gönül Dönmez Colin'den gelmiştir. Yazar, Hindistan, Pakistan, Bangladeş, Malezya, Endonezya, İran, Özbekistan, Kazakistan ve Türkiye sinemasında kadınların nasıl yer aldığına bakar. İslam toplumunda sinemanın çokeşliliği, erkek egemenliğini, çocuk yaşta evlilikleri, namus cinayetlerini vb. toplumsal yaraları nasıl sömürdüğünü problematize eder.

13 Din psikolojisi perspektifinden sinema ve din konusuna eğilen erken dönem bir çalışma için Bkz: Lüleci, Y. (2007). Sinema ve Din: Türk Sineması Örneği. (Yayımlanmamış Yüksek Lisans Tezi). Marmara Üniversitesi Sosyal Bilimler Enstitüsü, İstanbul. İlahiyat perspektifinden din ve sinema konusuna dair diğer güncel çalışmalar için Bkz: Uzdu, H. (2016). Modernleşme Sürecinde Türk Sineması ve Din. Uluslararası Sosyal Araştırmalar Dergisi, 9(42), 1164-1172; Yorulmaz, B. \& Blizek, W. L. (2014). Islam in Turkish Cinema. Journal of Religion \& Film. https://igitalcommons.unomaha.edu/jrf/volı/iss2/8; Koç, M. (2016). Değerler Psikolojisi Perspektifinden Türk Sinemasinda Din Görevlisi İmaji: 'Değer-Yoksun Dindarlik' Tipolojisi Bağlaminda Semantik Analizler. Dokuz Eүlül Ünivesitesi İlahiyat Fakültesi Dergisi, Din Piskolojisi Özel Sayısı, s. 191-249; Şenat, F. A. (2016). Kur'an Konularını Görsel Dille Anlatmanın İmkânı Üzerine. Bitlis Eren Üniversitesi Sosyal Bilimler Enstitüsü Dergisi, 5, 267-284.

14 Türkiye'de dini sinemanın aldığı farklı isimler: "Yeşil sinema", "Beyaz sinema", "Milli sinema", "Hidayet sineması", "İslami Sinema" vb. 70'lerin bu konuda bir milat olduğu kabul edilmektedir. İslamcılığın siyasal bir hareket olarak meclise girdiği yıllarda sinemada da yankısını bulan bu hareketin başlatıcısı olarak anılan Yücel Çakmaklı'nın filmlerini Nijat Özön "dini-ahlaki melodramlar" olarak adlandırır (aktaran Yaylagül, 2012, s. 46). Alanın önde gelen diğer yönetmenleri Mesut Uçakan, İsmail Güneş, Mehmet Tanrısever, Metin Çamurcu, Salih Diriklik ve Nurettin Özel gibi isimlerdir. Bu konuda bkz. M. Akser (T.Y.). Türk Sinemasında Dini Filmler: Gelenekçiliğin Modernleşmesi. http://panorama.khas.edu.tr/turk-sinemasinda-dini-filmler-gelenekciligin-modernlesmesi-113. 
sini sunar. Bilal Yorulmaz sinemanin psikolojik ve sosyolojik gücünün din eğitiminde nasıl kullanılabileceğine yanıt arar (2015). Aynı yazar bir başka kitabında (2016) Hollywood başta olmak üzere popüler sinemada Hristiyanllk, Siyonizm, Budizm ve Hinduizm'in filmlerde alt metin olarak propaganda amaçlı kullanıldığını iddia eder (2016). Mayıs 2015'te İstanbul'da Türkiye'nin ilk "Sinema ve Din" sempozyumu gerçekleştirilmiştir. Düzenleme kuruluna ve yer verdiği konu başlıklarına ${ }^{15}$ bakıldığında, bu alandaki çalışmaların seyrine paralel olarak sempozyumun da İslam teolojisi ağırlıklı bir çerçevesi olduğu görülmektedir.

Sinema ve din konusuna seküler bir perspektiften bakan ve bir tür olarak doğrudan dinsel sinema konusuna eğilen çalışmaların sayıca azlığı, Türkiye'nin akademik gündeminde, özellikle ilahiyat alanı dışındaki sosyal bilimler alanında, konunun geniş perspektifli ele alınmasının ihmal edildiğini düşündürmektedir. Meseleye seküler bir perspektiften bakan sınırlı sayıda güncel çalışma, yakın dönem Türkiye sinemasında dinin sosyo-ekonomik ve politik bir kurum olarak ele alınması (Yaylagül, 2012), korku filmlerinde dinsel unsurların kullanımı (Şimşek, 2016; Türkel ve Kasap, 2014), 2000'lerden sonra İslami sinemanın değişen seyrinin tasavvuf çerçevesinde yorumlanması (Maktav, 2010) gibi konulara eğilmiştir. Bu çalışmada ise, yerleşik toplumsal cinsiyet rollerine itirazın dinsel komedi ile nasıl mümkün olduğu sorusu sorulmakta, bunun yanı sıra, kutsal din figürlerini mizah malzemesi yapmakla birlikte dinsel komedide din temelli bir gündelik hayat tasarısının esas hikâye örgüsünü nasıl tesis ettiğine odaklanılmaktadır.

\section{Din, Mizah ve Dinsel Komedi}

Yerleşik dini kurumlar, mizahın türlü biçimlerine savaş açmış, "dini mizaha alet etmek" suçu büyük günahlar arasında sağlam bir yer edinmiştir. İnsanın üzerinde yarattığı tesir açısından din ve komediyi birbiri ile örtüşmez bulan bakış açıları (örneğin Hamilton, 1959, s. 807) mizahın inançtan alınan zevkin yerini ikame ettiğine vurgu yapar (Thompson, 1994, s. 68). Mizahın aksine din hazzı erteler. Birinde dünyevi zevklere, diğerinde ise ilahi olana dair bir vaat vardır. Mizah ve din ilişkisine tem-

15 Konu başlıkları Sempozyum'un web sayfasında şöyle sıralanmaktadır: Sinema ve İslamofobi, İslam Hukuku ve Sinema, İslam Sanatları ve Sinema, Sinema ve Dinler Tarihi, Sinema ve Kuran Ayetleri, İslami Sinema, Sinemanın İslamileştirilmesi, Sinema ve Kelam, Sinema ve Din Eğitimi vb. Sempozyuma dair detaylı bilgi için Bkz. http://sinemavedin.com/tr. 
kinle yaklaşan ve din açısından mizahın tekinsiz bir alan olduğu perspektifinden bakanlar ise bu iki alanın aralarındaki güvensizliği öne çıkarmışlardır (Saroglou, 2002). Zira mizah ve din ilişkisini psikoloji bağlamında ele alan Vassilis Saroglou, dindar kişilik özelliklerinde insanın kendini ve duygularını kontrol etmesinin öne çıktığından söz eder. Bununla bağlantılı olarak, kontrolü elden bırakmaya davet çıkaran kahkaha ile mesafeli bir ilişki vardır. Örneğin, diğerkamlık dindar hayatta esas alındığı için başkasının gülünç duruma düşmesini mizah konusu yapmak kabul edilemezdir. Saroglou'nun ifadesiyle (2002, s. 204) erken dönem Hristiyanllk, teoride ve pratikte insanın hayat neşesini ifade eden kahkahaya izin verir; fakat düşmanlık ve karalama amaçlı mizahı yasaklar. Ortaçağda gülmenin askıya alınması bununla ilintilidir. Çağdaş dönem dinsel düşünde de bu ayrım sürmektedir. İyi, ahlaklı ve onay gören mizah ile kötü ve başkasına saygı duymayan mizah net olarak ayrılır. Ayrıca Saroglou dinsel metinlerde vurgu yapılan hoşgörülülük ve kardeşlik gibi değerler sayesinde bir yandan da dindar insanın bilakis iyi bir mizah anlayışına dine rağmen değil, din sayesinde erişebileceğine işaret eder (2002). Tam da bu noktada dinsel olan ile mizahın ikircikli ilişkisi yine öne çıkar. Dinsel mizahın karikatür, film gibi örneklerine gösterilen tolerans eşiği, burada bahsi geçen iyi mizah-kötü mizah ayrımına muhakkak temas etmektedir.

Din ve mizah arasındaki ince nüansları gözetmekle birlikte, birbirleri ile bağlarını ve yakınlıklarını göz önünde bulunduran bakış açıları, hayata dair daha genel bir çerçeveden yaklaşırlar. Her şeyden önce, dinsel metinlerde de tıpkı komedi metinlerinde olduğu gibi, türlü zorluklara rağmen bir mutlu son beklentisi bâkidir. Trajedi, komedi ve din insanın arzularına, zayıflıklarına, zaaflarına, korkularına ve hayatın ve ölümün gerçekliği karşısındaki duygu karmaşıklığına yanıt olarak anlam ürettiği, üç farklı ve birbiri ile örtüşen alandır. Her üçü de hayatın yaşam ve ölüm, iyilik ve kötülük gibi uyuşmazlıkları (incongruity) karşısında, insanın deneyimine odaklanarak yanıtlar arar. Üçü de benzer konuları mesele edinir, fakat verdikleri yanıtlarda ayrışırlar. John Morreall (1999) hayatın uyuşmazlıklarına, örneğin savaşa, trajedinin yanıtının öfke ve isyan iken komedide "gülüp geçme", başa çıkma ve hayattan keyif almanın bir unsuru haline getirmenin ağır bastığını hatırlatır. Dinin yanıtında ise açıklamaların, tavsiye ve emirlerin hâkimiyeti vardır. Morreall'in işaret ettiği bu noktadan hareketle, komedinin hayattaki felaketlerle ilişkisinin, ciddiye alma değil alaya alma biçiminde seyrettiği söylenebilir. En büyük felaketlerden biri olan ölümün komediye bu kadar konu olmasında, me- 
selenin ciddiyetini askıya alma ve bu yolla onunla başa çıkma duygusu önemli bir roldedir.

Komedinin duyguları serbestleştirici, şimdi ve burada olan, hakiki problem ve sıkıntılardan özgürleştirici, insanı güçlü kılan bir yönü vardır (Morreall, 1999). Din ve komedinin birbiri ile benzerlik ilişkisini kuran yaklaşımların önemli bir temsilcisi Morreall'a göre dinsel metinler, özü itibariyle insana Tanrı'dan başka hiçbir şeyi fazla ciddiye almaması gerektiği mesajı verirken, diğer yanıyla, aşkın bir ciddiyete methiyeler ve ciddiyetsizliğe lanetlemeler de içermektedir. Bu uyuşmazlık, insan hayatındaki uyuşmazlıklardan, çelişki ve çatışmalardan farklı değildir. Bu noktada insanın düşünsel esneklik kapasitesi önem kazanmaktadır. Esasinda dozu iyi ayarlanmamış ciddiyetin dini fanatizmi beslediğine işaret eden Morreall (1999, s. 48), mizahın gereksiz aşırı ciddiye alma halinin en güçlü panzehiri olduğunu düşündürür. Zira yaratıcı düşünebilme ve düşünsel esneklik, aşırı ciddiyet ile bir arada barınamaz ve mizahtan beslenir. Nietzsche'ye referansla Morreall acılar, ıstırap ve yenilgiler üzerine kurulu insan hayatının ancak kahkahanın icadı ile sürdürülebilir olduğu görüşünü hatırlatır. Morreall'in "trajik duygular" adını verdiği öfke, korku ve üzüntü ancak insanı diğer memelilerden ayıran gülme ve mizah ile teskin edilebilir. ${ }^{16}$ İnsanın öfke, korku, üzüntü gibi temel duygularla başa çıkması mizahın olduğu kadar dinin de bir işlevidir. Morreall, din ve komedinin benzerliğini buradan kurar. Dinler insanı trajik duygularını bertaraf edebilme erdemliliğine davet eder. Mizah ise başlı başına bu erdem üzerine kuruludur. Mizah, insanın entelektüel ve ahlaki erdemidir. Dinsel fanatizm tam da burada bahsi geçen "trajik duygular"ın aşırı derecede açığa çıkmasıyla ve insanın kendini aşırı ciddiye alarak hayata tümüyle kendi perspektifiyle ve kendi doğrularıyla sınırlı, katı ve dar görüşlü bir bakış sunmasıyla ilişkilidir. Oysa mizah, insanın kendine mesafe koyabilmesini, benliğini aşarak resmin tümünü görebilmesini sağlar. Mizah, dogmatizmin karşısındadır. Hayatı dogmalar üzerinden algılayanlarda mizah perspektifi düşüktür. Benzer şekilde otoriteryanizm de mizahla negatif bir ilişki içerisindedir ki dinsel fanatizmin otoriteryanizm ile güçlü bağları bulunmaktadır (Saroglou, 2002, s. 194). İnsanın çeşitliliği ve

16 Morreal mizaha evrimci bir perspektif de sunar. Evrim sürecinde diğer memelilerde bulunmayan yeni bir yanıttır mizah. Avcı-toplayıcı insan hayatta kalabilmek, tehlikeler karşısında kendini korumak ve kendini ifade edebilmek için öfke, korku, üzüntü gibi temel duygulara gereksinim duyarken beynin limbik sistemi merkezdedir. Evrimin ilerleyen evrelerinde ise beyin nerokorteks merkezli işler; sofistike düşünmenin ve mizahın gelişebildiği yer de burasıdır (1999, s. 149). 
farklılığı, tevazusu ve hoşgörüsü, zayıflıklara ve hatalara sebat, mizahta açığa çıkar. Tam da bu nedenle bağışlayıcılık ve esneklik de mizah ile güçlenir. Mizah, zayıflık ve hata yapmak gibi kusurların, insanlık durumunun olağan bileşeni olduğunu anlar ve anlatır. Nihayetinde dinler insanlık durumlarına dair bir perspektif sunarken komedi de insanlık durumuna hakikatli bir bakışa imkân sağlaması ile bir nevi dinsel olanın amacını paylaşmaktadır.

Komedinin en büyük erdemi, insanın hayattan beklentileri ve yaşam deneyimleri arasındaki uyuşmazlıklarına ışık tutmasıdır. Conrad Hyers (1968), komedinin dinsel olan ve gündelik hayat arasında bir köprü olduğu görüşündedir. Kutsal olanın komediye ve kahkahaya ihtiyacı vardır. Nasıl ki hükümdarlar gülünç hallerini gösteren ve aslında kendilerini bulmalarını, despotizme savrulmamalarını sağlayan saray soytarılarına gereksinim duymuşlarsa, kutsal olan da mutlaklaşmamak için komediye gereksinim duyar. Kutsallık ve mizah arasındaki dengede tıpkı komedinin de kutsal olana ihtiyaç duyması gibi (Hyers, 1968). Peter Berger de (2014, s. 190) mizah ve inanç arasındaki bağı arınma, kefaret ve aşkınlık üzerinden kurar. Komedi, gerçek yaşamın yasalarının ve kabullerinin bir süreliğine askıya alınmasını, onu aşarak başka bir dünya tahayyülü içine girilmesini sağlar. Tıpkı dini ritüellerin sağladığı gibi bir aşkınlık ve arınma duygusu tesis eder bu yönüyle. Düşük perdeden sunduğu aşkın deneyimle komedi, gerçek dünyayı ters yüz eder, aşina olunanı yabancılaştırır. Saçmalama, kahkaha ve oyun için alan açan komedi, kutsal olanı cismanileştirerek askıya alır; dinsel olanın sorgusuz-sualsiz otoritesini sorgular, kutsalın üstün konumunu paranteze alır, uhrevi olanla cismani olan arasındaki derin mesafeyi en aza indirir. İnsanın hükümranlığa ya da ona benzer her türden güce karşı itirazını içinde barındırır (Hyers, 1968, s. 75).

Umutsuzluk ve çaresizlikle zorlu bir mücadele biçimidir mizah aynı zamanda. Çünkü mizahın olduğu yerde umut ve dirayet vardır. Hyers'e göre (1968) komediyi dinsel olana yaklaştıran, en umutsuz anda bile gülmeyi sağlayarak insana aşıladığı umuda benzer biçimde dinsel olanın da kader öğretisi ve ilahi adalet öngörüsü ile insana benzer bir kurtuluş umudunu aşılamasıdır. İkisinde de büyük mucizeler, beklenmeyen sürprizler mevcuttur. Hyers'in dikkat çektiği önemli bir diğer husus ise, hiç kimsenin aşina olmadığı, yakınında olmayan bir şey hakkında mizah üretemeyeceği gerçeğidir. Komedinin dinsel olan ile bağı buradan da ileri gelmektedir. Her hâlükârda komedide insanın benliğinin ve hayatının farkına varmasını sağlayan etik açısından önemli bir rol her daim mev- 
cuttur. Dinsel komedide bu, inancı hem merkeze alma, hem onun ürettiği kurumları hicvetme, hem de onsuz bir hayat tahayyülü sunmama biçiminde görünür olmaktadır. Tıpkı The Brand New Testament'ta olduğu gibi.

\section{Mizahta Tanrı}

Gülmenin sınırı kültüre, yaşanılan zamanın ruhuna ve toplumların ortak müzakerelerine göre belirlenir. Kutsal figürleri komedi unsuru yapmak, bir tarafta ifade özgürlüğü adına savunulurken diğer tarafta ölüm tehditleri ve ağır hukuki yaptırımlar gibi riskleri göğüslemeyi gerektirmektedir. Kutsal figürleri komedi unsuru yapmada öncü bir kültürel iklim sunan Hristiyanllkta, en kutsal dini figürlerin mizaha konu olmasının ilk örnekleri önce sözlü ifade biçimleri, ardından gravürler ve çizimler ile ortaya konmuştur.

Dinsel mizahın öncelikle sözel anlatılarda ortaya çıkmasından sonra görsel formlarda geliştiği dikkate alındığında, Tanrı'nın mizah ile biraradalığının, dilsel mizahta en yaygın biçimlerinden birinin fikralar olduğu akla gelmektedir. Öldükten sonra Tanrı'nın huzuruna çıkan günahkâr, ateist, dindar anlatıları ile esasında bu fikralarda Tanrı'nın otoritesi, aklı ve gücü onaylanır. Dilsel mizah içerisinde Tanrı'nın komedi unsurunun bir parçası olduğu bir başka alan ise stand-up komedilerdir. Amerika'da yaygın örneklerine rastlanan bu türde de Tanrı'nın merkezde olduğu bir hayat tahayyülünün mizah üzerinden anlatımı vardır. Apostles of Comedy (2008), Thou Shalt Laugh (2006-2011) gibi örnekleri inceleyen Elisha Mclntyre (2013) Tanrı ve peygamberler hakkında komedi içeriklerinde dine hakaret ya da kutsal değerleri rencide edecek unsurlar yer almadığı gibi, aksine inancı besleyen ve Hristiyan dünyasını olumlayan bir anlatımın hâkim olduğunu tespit eder. ${ }^{17}$ McIntyre (2013) bu tarz içeriklerde Tanrı'nın her şeye kadir olduğu mesajı ile çelişen bir husus olmadığı gibi, teknoloji kullanımında bile O'nun varlığı söz konusudur, gibi bir okuma-

17 Örneğin Thou Shalt Laugh'da (2006) bir espri şöyledir: "Tanrı ergen çocukları insanlıktan intikam almak için yarattı. İnsanlara baktı ve şöyle dedi: 'Kendi suretinde birini yaratmak ve sonra da yarattığın kişi tarafından yok sayılmak neymiş bir görsünler bakalım"' (McIntyre, 2013, s. 104). Burada hem Tanrı'nın varlığı onaylanır hem de Tanrı'nın da mizahı hoş gördüğü mesajı verilir. Aynı şovun ikinci serisinde (Thou Shalt Laugh 2, 2007) Tanrı ile telefon görüşmesi yapılır. Başkarakter önce İsa'yı arar ve Tanrı ile telefonda görüşmek istediğini söyler. Ardından Tanrı ile telefonda konuşulur. Tan$\mathrm{rl}$, arayan kişi hakkında detaylı bilgi almak için Google'da isim ve soy isim bilgisini girerek arama yapar. Burada ilk bakışta Tanrı'nın sıradan insan gibi sunulması, onun kutsallığını yadsıyan ve küçük düşürücü bir etki gibi okunabilir. 
nın da mümkün olduğu görüşündedir. Esasında Tanrı'yı konu alan komedilerde ortak olan mesaj, komik olanın Tanrı'nın kendisi, yasaları ya da eylemleri olmadığı, onları yanlış yorumlayanların ya da O'nun varlığını reddedenlerin esas mizah malzemesi olduğudur.

Tanrı'nın görselleştirilerek mizah konusu yapılması ise, daha tartışmalı bir konudur. İslamiyet ve Yahudilikte Tanrı'nın erişilmezliği ve aşlmaz mesafesi, onun ve Peygamber'in herhangi bir şekilde görsel olarak imgeselleştirilmesini yasaklama yoluyla ifade edilmektedir. ${ }^{18}$ Hristiyanlıkta da bir dönem etkili olan ikonoklast gelenek, Tanrı'nın görsel tasvirle değil, sözle ve soyutlamalarla anlatılmasını açıklar ${ }^{19}$ (Anker, 2004, s. 8). Hristiyan dünyada, farklı tarihsel dönemlere ve farklı mezheplere göre yaklaşım farklılıkları olmakla birlikte, Tanrı'nın, ikonografik ifadesi ve insan suretinde tezahürü mümkün olmuştur. ${ }^{20} \mathrm{~Hz}$. İsa ve haç figürlerinin erken dönem örnekleri MS. 5. yüzyılda görülürken, Hristiyanlığı yeren ve kutsal figürlerini alaya alan grafitilerin izleri, Roma'daki Palatine Tepesi yakınlarında, Hristiyanlığı seçenlerin toplumdan dışlandığı ve tanrıtanımaz ilan edildiği MS. 3. yüzyıla kadar gitmektedir (Boespflug, 2011). Öte yandan, Hristiyanlığın kabul görmesi ve dini kurumların yerleşikleşmesini takiben Tanrı, Peygamber ve diğer kutsal kişilerin görsel ifadeleri yaygınlaşmış ve ortaçağı kapsayacak şekilde dokunulmazlığa sahip olmuştur. ${ }^{21}$ Dine hakaret, Tanrı ve kutsal figürlerin isimlerini kö-

18 Danimarka'da Jyllands-Posten gazetesinde Eylül 2005'te yayınlanan Hz. Muhammed karikatürleri Danimarka'da ve Avrupa'nın çeşitli ülkelerinde Müslüman gruplarca büyük protestolara neden olmuştur. Tepkiler Ortadoğu'ya da uzanmış, protesto gösterileri 200'e yakın insanın hayatına mal olmuştur. Eylül 2012'de Fransa'da Charlie Hebdo dergisi Hz. Muhammed karikatürü yayınlamış, bunu gerekçe göstererek dergiye yapılan silahlı saldırıda 12 kişi yaşamını yitirmiştir. Tüm bu ve benzeri "İslam'ın kutsal figürleri hakkında mizah" girişimleri ifade özgürlüğü ve dinsel değerlere saygısızlık bağlamında tartışılmıştır.

19 Tanrı'nın farklı dinlerde imgeselleştirilmesine dair Bkz. Besançon, A. (2000). The Forbidden Image: An Intellectual History Of Iconoclasm. University of Chicago Press. İslam sanatlarında figüratif süslemeler, kaligrafi ve minyatür, görsel ifadenin öne çıkan biçimleridir. İslam'da mizaha ve sanatsal ifade biçimlerine dair bkz. Marzolph, U. (2011). The Muslim Sense of Humor. H. Geybels \& W. Van Heck (Eds.), Humor and Religion (169-188). London: Continuum. Ayrıca Kuran'dan ve hadislerden örneklerle gülmeye ve gülmeceye İslamiyet'te nasıl yaklaşıldığını ele alan bir çalışma için Bkz. Tamer, G. (2009). The Qur'an and Humor. G. Tamer (Ed.), Humor in Arabic Culture ( 3-28 ). Berlin: Walter de Gruyter.

20 Bkz. Schoenborn, C. C. (1994). God's Human Face: The Christ Icon. Ignatius Press.

21 Popüler kültür ve ikonoloji ilişkisi çerçevesinde dinsel ikonoloji ve onun çağdaş dünyadaki versiyonu bağlamında laik ikonolojinin benzerliklerini ve ayrışma noktalarını ele alan Ünsal Oskay, sihire dayanan eski dinlerin çoğunda da ikonların önemli bir yeri 
tüye kullanmak ve kutsal değerleri uygunsuz resmetmek, en ağır suçlardan sayılmıştır. ${ }^{22}$ Rönesans'ta Papa ve din adamlarına yönelik eleştirel sanatsal ifade biçimleri ortaya çıksa da Tanrı, İsa Peygamber ve Meryem Ana'nın dokunulmazlıkları sürmüştür.

Tanrı'nın nadir olarak mizaha konu olmaya başladığı ilk örnekler, 18. yüzyıl sonlarında İngiltere ve Fransa'da görülür. İngiltere'de James Gillray'in anti-katolik politik karikatürleri ve Fransa'da devrimle ilgili gravürlerde Tanrı yer alsa da esas komedi unsurları yine din adamlarıdır. 19. yüzyılda, Aydınlanmacı, rasyonalist fikirler ve ifade özgürlüğü anlamında verilen mücadeleler dinsel kutsallara dokunan sanatsal içeriklerin kendine daha sağlam zemin bulmasını sağlamıştır. Bu konuda, özellikle "karikatür başkenti" Paris, başı çekmiştir. Paris Komünü sırasında Tanrı'yı hicveden imgeler ilk kez dolaşıma girmiştir. Diğer yandan, Fransa'da 19. yüzyılda din karşıtı karikatürlere karşı önlemler alma yoluna gidilmiştir. Belçika ve Almanya, İngiltere ve Amerika'da dini değerlere hakaret edenlere, kamu düzenini bozmak ve insanların dini duygularını rencide etmek nedeniyle cezalar verildiği görülmüştür. 20. yüzyılda yine Fransa'da, Tanrı'nın kutsallığına müdahale eden anlatımlara ve ifadelere daha sık rastlanır. 5-11 Kasım 1990 tarihli La Nouvel Observateur gazetesinde "Tanrı kadın düşmanı mı?" başlıklı bir yazı yayınlanmış ve herhangi bir reaksiyonla karşılaşmamıştır (Boespflug, 2011, s. 213). Bu genel hoşgörülü yaklaşım 2000'lerde karikatürlerde en kutsal dini figürlerin yer almasının olağan bulunmasını da anlaşlır hale getirir. Grafik ya da edebi formlarda Tanrı ve diğer kutsal figürlere dair mizah dilinde üretim yapmanın Hristiyan dünyada nasıl bir tarihsel izlekte bugünlere ulaştığına dair Boespflug'un sunduğu tarihsel izlek dinsel mizahın gelişmesinde ve Tanrı'nın mizah unsuru haline gelmesinde karikatürün merkezi bir yerde olduğunu gösterir. Ayrıca bugün dinsel komedi filmlerinin ve Tanrı'yı gülmece unsuru haline getiren içeriklerin neden Hristiyan dünyada ağırlık kazandığını da açıklamaktadır. ${ }^{23}$

olduğuna işaret eder (2000, s. 179-192).

22 Bakhtinyan karnavalların, festivallerin mizaha alan açtığı bu dönemde Hristiyan dünyasında görsel yolla alay konusu yapılabilen yegane dinsel unsur Yahudiliktir. Saint Lous İncili'ndeki ikonları ele alan François Boespflug (2011, s. 207), Tanrıya ve haça arkasını dönen, dilini çıkaran, deforme edilmiş bir yüzle ifade edilen Yahudilerin olduğu resimleri örnek verir.

23 Hristiyanlık'ta kutsal figürlerin mizah konusu olmasına dair ayrıca bkz. Darden, R. (2011). Jesus Laughed: The Redemptive Power of Humor. Nashville: Abingdon Press. 


\section{Dinsel Komedi Filmlerinde Tanrı ve The Brand New Testament}

Tanrı, farklı film türlerinde soyutlamalarla ve farklı imgelerle konu edilmiştir (Örneğin Time Bandits, 1981; Dogma; Star Trek V., 1989). Fakat Tanrı'nın insan suretinde bir film karakteri olduğu örnekler de komedi filmlerinde mevcuttur. Tanrı'nın bir film karakteri olarak canlandırıldığı filmlerde Tanrı karakterinin Yahudi-Hristiyan geleneği üzerinden temsil edilmesi yaygındır (Mazur, 2011, s. 197-203). Bu filmlere örnek olarak, her ikisi de komedi türünde olan Oh God (1977) ve Bruce Almighty'de Tanrı'ya işini neden tam olarak yapmadığı minvalinde sorular sorulur (Lamm, 1991). Örneğin istese beş dakikada bir şeyi düzeltebilecekken bunu neden yapmadığı gibi. Oh God'da Tanrı'nın yanıtı açıktır: "Her şeyi Tanrı'dan beklemeyin ve insanlık olarak elinizi taşın altına koyun". Oh, God! Book II'de (1980) ise "kötülüklerin olmasına neden izin veriyorsun" sorusuna Tanrı, "bazen kötü bir şey herkes için kötü olmayabilir. Kötülük de iyilik gibi sistemin bir parçası" yanıtını verir. Her şey zıddıyla anlamlıdır. Kötülük ve iyilik, yaşam ve ölüm, haz ve acı. Morgan Freeman'ın Tanrı'yı canlandırdığı Bruce Almighty'de durum biraz farklıdır. Tanrı tatile gider ve bir süreliğine Bruce (Jim Carrey) Tanrı'nın yerini alır. Tanrı olmanın hiç de kolay olmadığını deneyimler: İşini kolaylaştırmak için herkesin duasına bilgisayarından otomatik yanıtlayıcıyı devreye sokarak "evet" yanıtını verdiğinde binlerce insanın piyango kazanmasıyla büyük kaos yaşanır. $\mathrm{Bu}$ filmler esasında din-yanlısı ve Tanrı'ya Tanrı ile birlikte gülmeye davet eden komedilerdir (Lamm, 1991).

"Tanrı'ya gülebilir miyiz?" sorusuna Gülün Adı filmi üzerinden yanit veren Robert Lamm (1991), meseleye komedinin temel işlevi olarak gördüğü, korkuyu "ortadan kaldırma" gücü bağlamında yaklaşır. Gülün Adı'nda Brother Jorge karakteri "korku olmadan inanç olmaz, şeytandan korkmayanın Tanrı'ya ihtiyacı kalmaz" sözlerini sarf eder. Filmin başkarakteri Brother William of Baskerville ise, aksine komedinin batıl inanışları ve yanlış Tanrı kavrayışlarını giderdiğine inanır ve izleyiciye bu yönde mesajlar verir. Lamm (1991) seküler komedi ve dinsel komedi ayrımını da benzer bir fikir ile ilişkilendirir. Dinsel komedinin insanlığa ve dünyaya dair tahayyülünde Tanrı ve dinsel figürler merkezdedir. Bu da esasında dinsel komedi metninde Tanrı inancına uzak değil, bilakis bu inançtan beslenen ve inancı esas alan bir yaşam kurgusu olduğunu düşündürür. 
The Brand New Testament da dini merkeze alan olay örgüsü ile dinsel komedi türündedir. Filmde bir yandan ataerkil dünyanın esas sorumlusu olarak dinsel kurumlar işaret edilir ve yerilirken bir yandan da hayata dair her şeye din temelli ve inancı onaylayan bir açıklama getirilir. Agresif ve acımasız çizilen bir Tanrı Baba, dünyayı yönettiği özel odasında, Murphy Kanunları'nın sürekliliği işi ile uğraşmaktadır: Reçelli ekmek yere düştüğünde muhakkak reçelli olan taraf yere değecektir, uzun bir kuyrukta sıradaysanız her zaman diğer sıra daha çabuk ilerleyecektir gibi. Tanrı'nın hayatı daha yaşanılır bir hale getirmek isteyen kızı Ea ile çatışmalı ilişkisini anlatan filmde Ea'nın annesi de Tanrı'nın evreni yönettiği sistemi tesadüfen ele geçirince Tanrıça eliyle dünya bambaşka bir yer olur. Önce Ea, Tanrı babasının dünyayı ve tüm evreni yönettiği bilgisayarı hack'leyerek O'nun tüm gizli sırlarını ele geçirir. Bunlar arasında en önemlisi, insanların yakın-uzak gelecekteki ölüm tarihleridir. Herkese ölüm tarihini cep telefonu mesajı ile iletir. Ağabeyi JC'nin yönlendirmesiyle yeni bir ahit yazmaya ve yeni havariler bulmaya koyulur. Evdeki çamaşır makinesinin içine girerek babasından kaçan Ea, kendini dünyada bulur. Tanıştığı bir evsizin, Victor'un yardımı ile altı havarisini bulmak üzere yola koyulur. ${ }^{24}$ Yeni havarilerin ve Ea'nın sözlerinden ve deneyimlerinden oluşacak En Yeni Ahit'i Victor kaleme alacaktır. Victor'un hayatta en önem verdiği "hayat bir buz pistidir ve herkes düşer"dir sözü de En Yeni Ahit'te yer bulacaktır. Filmde bir yandan dünyada kötülüklerin, şiddetin ve yıkımların kaynağı olarak Tanrı'nın cinsiyetine göndermede bulunulurken diğer yandan hayattaki her şeyin kader ile tayin edildiği görüşü doğrulanır. Filmde başka bir dünya arzusu ve tahayyülü, Tanrı'nın erkekliğine vurgu yapılarak mizah yoluyla hikâyeleştirilir. "Kadın eli değmiş gibi" deyimi Tanrıça'nın dokunuşları ile hayata geçer.

\section{The Brand New Testament'te Alternatif Dünya Kurgusu: Babasız Dünya ve Babalık Krizi}

Filmde Tanrı, şiddet uygulayan, sevgisiz bir eş ve baba olarak çizilir. İnsanlığı aslında can sıkıntısından yaratmıştır. Zira evde mutlu değildir. Karısını ve çocuklarını sevmez. Sevgisizliğinin temelinde ise, hiçbir zaman aşk yaşamadığı karısı ile ilişkisi yatmaktadır. Bunu sözleriyle sık sık

24 Altı havari bulma fikri Ea'nın ağabeyi JC'ye aittir. Mantığı, filmdeki anlatıma göre şöyledir: Anneleri beysbol hayranıdır. Beysbol maçı 18 kişi ile oynanır. 12 havariye 6 kişi daha eklerlerse 18 rakamına ulaşacaklardır. Bu da, 12 kişi ile oynanan hokey hayranı Tanrı-Baba'ya bir itirazdır. 
ifade eder. Bu aslında kutsal bakire Meryem Ana'ya bir gönderme olarak da okunabilir. Aşkın ve cinselliğin olmadığı bir ilişkinin ürünü olan çocuklardır Ea ve ağabeyi JC. Tanrı-Baba "Evrensel Istırap Yasaları"nı yazdığı bilgisayarının başında mutludur sadece. Örneğin: "Yasa 2228: Kasada yandaki sıra her zaman daha hızlı ilerler". Bir diğer yasa, kendisinin de mustarip olduğu durumu özetler gibidir: "Aşık olduğun kişi ile hayatını sürdürememen kuvvetle muhtemel."

Tanrı-Baba, filmdeki tabiriyle "insanları çileden çıkaran yasa maddeleri"ni yazıp uygularken sevinç çığlıkları atar. Dünyayı yönettiği ofisi, evdeki yasak bölgedir. Kimsenin girmesine izin yoktur. Anahtar da sadece kendisindedir. Fakat Ea bir gün bu ofisi keşfeder ve içeri sızmayı başarır. Babasının yaptıkları karşısında büyük bir üzüntü duyar ve öfkeye kapılır. Ea yemek masasında bakışlarıyla bardağı yerinden oynatır. Babası "Ea kes, Sen Abin değilsin!" diye bağırır. Bu, Tanrı-Babanın elçisi olarak tayin ettiği peygamberlerin erkekliğine ve kadınların becerilerini geliştirme ve kendilerini ortaya koymalarına yönelik baskıcı tutumlara bir gönderme olarak okunabilir. Oysa Ea'nın mucizeler gerçekleştirebilme yeteneği vardır ve bu yönüyle insanları etkileyebilme gücüne sahiptir. Babasına "insanlara yaptığının ne kadar zalimce olduğunun farkında değilsin," der. "İnsanlara yaptıkların midemi bulandırıyor," diye ekler. Annesi bu söz karşısında büyük bir korku duyar. Sürekli içki içen, hokey maçı izleyen, karısına ve kızına sözlü ve fiziksel şiddet uygulayan biri olarak bu söz karşısında Tanrı-Baba dehşete kapılır. Kızının, dünyayı yönettiği gizli ofisine girdiğini öğrenir ve onu kovalamaya başlar. Kovalamacanın sonu, gaddar babaya dair bir film klişesi ile biter. Belindeki kemeri çıkarıp kızını döver. Ea için bardağı taşıran son damladır bu.

Ea evi terk etme kararı alır. Amacı, annesi ve kendisi için bir hapishaneye dönüşmüş olan hayatını geride bırakıp dünyaya gitmek ve bir şeylerin değişmesi için çabalamaktır. "Babamdan daha iyisini yapmak istiyorum. Fakat önce onun canını yakmak istiyorum," der. Evi terk etmeden önce bir kez daha, babası uyurken boynundaki anahtarı alır ve gizli ofise girer. Bilgisayar başına oturup ilk iş olarak tüm insanlığa ölüm tarihlerini kısa mesaj olarak yollar. Herkese ölüm tarihlerini yolladığını JC'ye söyler. JC bundan çok memnuniyet duyar ve "Babam tüm itibarını kaybedecek. Umarım deliye döner. Süper fikir," der. Baba-oğul çatışmasının en çok su yüzüne çıktığı sözdür bu. Filmde annesine bağlılığıyla çizilen JC, babaya karşı mücadelesi ile Oidipus'u çağrıştırır. Mitolojik anlatılarda Baba kahramanın, örneğin Satürn'ün saldırganlığı, kendi zayıflık 
duygusundan ve evlatları tarafından kuyusunun kazındığı korkusundan beslenir (Thoma, 2011, s. 72). Film boyunca, çeşitli sahnelerde Tanrı-Baba, oğlunun kendi otoritesini tanımamasından, 12 havarisi ile yanlış işler yapmasından ve babasının sözünden çıkmasından yakınır. Bir sahnede, kızı Ea'nın peşinden dünyaya giden Tanrı-Baba, kilisede rahiple birlikte oturmaktadır. Rahip İsa'nın heykeline bakarak "Ne güzel bir yüz. İnsana huzur veriyor," der ve ekler: "Tanrı der ki komşunu kendin gibi sev". Tanrı-Baba ise, "Ben öyle bir şey demedim. Ben kendimden nefret ediyorum. Şöyle diyorum ben aslında: Kendinden nasıl nefret ediyorsan komşundan da öyle nefret et". Rahip çok şaşırır bu sözler karşısında. Tanrı, İsa heykelini işaret ederek sözlerine şöyle devam eder: "Boş ver bu adamı sen. Kafasından uydurmuş. Hisleriyle hareket etmiş. Anladın mı?" Bu noktada oğlunu rakip olarak gören bir baba olarak konuşmasını sürdürür: "Ama ben Tanrı'yım. Her şeyi ben yarattım... Onun tek yaptığı kendini bir askılığa çiviletmek oldu. Baykuş gibi". Bu sözlerden yola çıkarak Tanrı'nın kendisi ile barışık olmadığı, kendini sevemeyen birinin ne çocuklarına ne de insanlığa sevgi verebileceği gibi bir yoruma da ulaşlabilir.

Tanrı, bir yandan evlatları tarafından sevilmemenin hırçınlığını da üstünde taşımaktadır. Bir sahnede Ea'ya "Zaten beni hiç sevmedin," der. Burada aslında erkekliği en tahakkümcü biçimiyle deneyimleyen Tanrı-Baba'nın, bir yandan kendi uyguladığı ataerkil şiddet yasaları tarafından nasıl ezildiğini, sevgisizlik karşısındaki yalnızlığı üzerinden görmek mümkündür. Baba figürü, filmde tam da geleneksel otoritenin temsilcisi ve ailedeki iktidarın sahibi olarak çizilmektedir. Çocuklarını sevgi ile değil, katı bir disiplinle eğiten, mesafeli ve şiddet uygulayan geleneksel baba figürünün bir yandan bir meşruiyet krizi içerisinde resmedildiği görülür. Söz konusu babalık krizi hem babanın şiddet uygulayarak elinde tutmaya çabaladığı iktidarın aslında yitirilmiş bir otorite ile ilişkisi olmasına hem de çocukların baba otoritesine isyanına tekabül eder. En yüksek patriarkı temsil eden Tanrı-Baba, kendi çocukları tarafından alaşağı edilmektedir. Ataerkil dünya düzeninin aile babası, işlevsizleşmekle yüz yüzedir. Tanrı-Babanın otorite kaybı, güçlerini Tanrı'dan alan ve patriyarkanın yeryüzündeki temsilcisi olan geleneksel babanın otorite kaybını sembolize eder. Babanın otorite kaybı, Ea'nın itirazında simgeleşen, kadınların hak taleplerinin ve mücadelelerinin yanı sira, JC'nin kendi yolunu izlemesinde temsil edilen, farklı erkekliklerin mümkün olduğuna dair itirazlar ile de vücut bulur. Bu aynı zamanda ataerkil aile düzeninin de yerinden edilmesine karşlık gelir. 
Eril şiddete dair yorumlarda en çok vurgulanan nokta, şiddete başvurmanın aslında bir tür iktidar ve itibar kaybına reaksiyon olarak da okunabileceği hususudur (Acar Savran, 2004; Arendt 2012; Çaylı Rahte, 2015). Hem insanlık hem de kendi çocukları tarafından yeterince dikkate alınmadığını hissetmenin ağır yükü vardır Tanrı-Baba'nın omuzlarında. İnsanlar O'ndan çok, dinsel anlatıları ve bu dinlerin elçilerini, aracılarını dikkate alır. Tanrı unutulmuştur bir nevi. Tanrı için otoritesini korumanın tek yolu, insanlara korku salmaktır. Ölüm korkusu da bunun başında gelmektedir. Ölüm korkusu olmadan Tanrı'nın otoritesini sürdürmesi imkânsızdır. $\mathrm{Bu}$, aynı zamanda patriyarkanın varlığını sürdürmesi için de eldeki en önemli kozdur: Korku yaratmak ve tahakküm kurmak. Korkunun olmadığı yerde tahakkümün araçları işlevsizleşir, tesisi güçleşir. Eril iktidarın kendini yeniden ürettiği ve varlığını sağlamlaştırdığı savaşlar, düşmanllk söylemleri, kana ve ölüme methiyelerle kurulu militarist pratikler alanı, patriyarkanın düşüşe geçişiyle birlikte itibar kaybeder. Ea'nın babasından korkmayarak ve onun hiddetinden kaçınmayarak inandığı yolda gitmesi, Tanrı-Baba'nın ev içinde ve ev dışında iktidar kaybının habercisidir. Babasız bir dünya kurgusu filme giderek hâkim olur. Ayrıca Ea'nın tüm insanlığa ölüm tarihlerini yollamasından sonra ölüme karşı hayatın değer ve anlam kazandığı yeni toplumsal iklimde, dünyada artık savaşlar durur. Zorunluluklar bir kenara atılır. Herkes hayallerini gerçekleştirmenin peşine düşer. Mesela 12 yılı kaldığını öğrenen biri, kibrit çöplerinden Titanik gemisi yapmak istediğini söyler sosyal medya üzerinden.

Babasız dünyaya hem psikanalizin hem de siyaset felsefesinin perspektifiyle yöneltilen eleştirilerde, hayatın belli bir düzen içinde seyretmesi için baba sevgisine ve otoritesine duyulan ihtiyaca gönderme yapılır. Siyaseten, politik babanın, dolayısıyla politik ataerkinin olmadığı bir toplumsal düzende evrenin başıbozukluğa ve kaosa sürüklenmesinden duyulan kaygı ön plandadır. Bu kaygı, özellikle feodal düzenin yıkıldığı, krallıkların yerini demokratik düzene bıraktığı büyük siyasal değişimlere referansla dile getirilmiştir (Thoma, 2011). Her şeye kadir, cezalandıran ve bağışlayan Baba-hükümdarların olmadığı yeni bir dünya düzeni karşı-devrimci cephede, belirsizleşen bir dünyada düzen kaybından duyulan kaygıya karşılık gelir. Kendi benliğini gerçekleştiren ve bireysel özerkliğini ilan eden, "öksüzlüğü" tercih eden özgür bireyin hayatında ne Tanrı'ya, ne babaya, ne de hükümdara sorgusuz ve sualsiz biata yer vardır. Babasız dünyada insanlar, Tanrı'nın çocukları oldukları için değil, 
kardeşliği kendi iradeleriyle seçtikleri için kardeşçe ve barış içinde yaşamayı seçerler. Tıpkı babalığın lağvedilmesini takiben Fransız devrimcilerinin, kardeşliği yeni politik düzenin hükümranı ilan etmesinde olduğu gibi. Böylece babanın erki yerini demokratik bir erke, bağımsız birey ve egemen yurttaşa bırakabilecektir.

Psikanalitik açıdan, baba otoritesinin kırıldığı bir toplum tahayyülüne Sigmund Freud'un Totem ve Tabu'su kaynaklık eder. Baba-oğul ilişkisi tutarsızlıklarla ve karşıtlıklarla örülüdür. Babaya hem sınırsız bir güç atfedilir hem de bu güçten duyulan korku, babaya duyulan nefreti besler. Babaya gösterilen güvensizlik, ona gösterilen saygıyla bir aradadır (Freud, 1998, s. 113-114). Babanın otoritesinin bertaraf edilmesinden sonra yeni bir baba özlemi baş gösterir. Babanın yerine getirdiği, üstlendiği vazifeleri yapacak bir otorite arayışı vardır. Bu otorite, modern demokraside, aslında baba rolü ile çocuk rolü arasından gidip gelen demokratik yurttaşın kendisidir. Otorite hem sorgulanır hem muhafaza edilir (Thoma, 2011, s. 190-191). Filmde söz konusu yeni otorite, annenin sevgi dolu otoritesidir.

\section{Patriyarka Eleştirisi ve Anaerkilliğe Övgü}

İnsanlığın ortaya çıkması ve toplumun oluşumuna dair filmin temel varsayımı, Tevrat ve İncil'deki "Yaratılış" anlatısını birebir yansıtmaktadır. Tanrı-Baba bilgisayarının başında "Yaratılış" adını verdiği bölümü yazmaya başlar. Önce dünyayı ve Brüksel'i yaratır. Şehir hayatının esas sakinleri olarak zürafa, tavuk, kaplan ve deve kuşu denemelerinden sonra daha eğlenceli bir şeyler yapmak ister ve insanı yaratır. Filmde söylendiği şekliyle "kendi suretinde bir adam yaratır". Bu kişi Adem'dir. Tipkı İncil'de geçtiği gibi Tanrı önce Adem'i yaratır ve ardından, ona tabi olacak Havva'yı yaratarak toplumun temelini atar. İncil anlatısı Tanrı'dan sonra en büyük otorite olarak tüm erkek-babaları tayin etmiştir. Tüm bir toplum, Adem'den türeyerek büyük bir aile oluşturur. Patriyarkal aile formunda Tanrı'dan sonra en büyük otorite Adem ve onun devamı olan oğullarıdır. Tüm dünya Adem için yaratılmıştır ve onun mülkiyetine sunulmuştur (Laslett, 1949). $\mathrm{Bu}$ anlatı tam olarak patriyarkal ailenin temelini kurar. Eski ve Yeni Ahit'te Yaratılış'ın süregelen çeviri ve yorumlarında egemen olan bu erkek üstünlüğü tınılı hâkim bakış yerine, İncil'de kadınlara dair olumlu imgelerin izini süren ve Woman's Bible'ı kaleme alan Elizabeth Cady Stanton (1898), "Tanrı'nın Sözü"nün daha özgürlükçü bir perspektifle tercüme edilebileceğine inanmıştır. Woman's Bible'in (Kadının İncili) "Yaratılış" bölümünde 
Stanton, en eski çevirilerde de rastlandığı şekliyle, Tanrı'nın kadını ve erkeği kendi suretinde ve eşzamanlı olarak yarattığına vurgu yapar. Çeviri şöyledir: (Yaratılış 1: 26-27) "...Ve Tanrı erkeği kendi suretinde yarattı, Tanrı'nın suretinde yarattı onu, kadın ve erkek suretinde onları yarattı...Ve onları kutsadı..." ${ }^{25}$ (Stanton, 1898). 19. yüzyıl kültürel feministlerinin Tanrı ve peygamberlerin cinsiyetinin erkek olmasina ve Kutsal Kitap'in son derece ataerkil bir dile tercüme edilmesine dair sorgulamaları, Tanrıçalara ve eski toplumlardaki anaerkil yapılara dair yazından yoğun olarak beslenmelerini beraberinde getirmiştir (Donovan, 2013).

The Brand New Testament, Tanrı'nın cinsiyetinin erkek oluşundan yola çıkarak ataerkil toplumsal düzene eleştiri getirir. Finale doğru Tanrı'nın cinsiyetinin kadın olduğu, Tanrıça tarafından yönetilen anaerkil bir yeni dünya hikâyesi sunmak suretiyle kültürel feminist geleneğin tartışmalarına katkıda bulunur. Filmin isminin "En Yeni Ahit" olması da Stanton başta olmak üzere kültürel feministlerin İncil'i yeniden tercüme etme ve anaerkillikle uyumlu bir dinsel anlatı kurma çabaları ile oldukça uyumludur. Filmin Yaratılış hikâyesi İncil'in genelgeçer ve ataerkil yorumu ile uyumludur. Fakat aynı zamanda filmin hikâyesinin bütünü, bu yoruma itiraz üzerinden kurulur. Filmde Adem ve Havva'nın çok sayıda çocuğu olur. Ve Ea'nın tabiri ile "Her şey o zaman başlar. Tanrı, insanları kendi adı uğruna birbirlerine düşürür. Savaşlar Tanrı adına yapılır". Burada bir patriyarka eleştirisinin ilk sinyali verilir. Tanrı baba, Ea'nın bu sözlerinin peşi sıra, evde sürekli maç izleyen, içki içen ve karısına ve kızına sürekli kötü muamele eden biri olarak sahnedeki yerini alır.

Patriyarka, erkeğin kadın üzerinde egemen olduğu, kadını ezdiği ve sömürdüğü toplumsal yapı olarak tanımlanır. Erkek şiddeti ise bu yapının önemli bir bileşenidir (Walby, 2016, s.139). Tanrı'nın şiddet meyilli bir eş ve baba olmasına gönderme yapılarak filmde patriyarkanın dünyadaki şiddetin, savaşların, bir başka deyişle, kötülüklerin nedeni olarak tayin edildiği gibi bir yoruma ulaşmak mümkündür. Zihinlere derinden nüfuz eden patriyarkal ideolojinin eleştirisinde oldukça temel bir hareket noktasıdır burası. Bu tür bir eleştirellikte şiddetin kadınlar arasında, erkekler arasında olduğundan çok daha düşük düzeyde olduğunun altı çizilir. Toplumsal iktidar, tahakküm yoluyla erkek elinde toplanır. Erkekliğe

25 Metnin İngilizcesi şöyledir: "27: So God created man in his own image, in the image of God created he him: male and female image, created he them.... 28: And God blessed them." 
dair eleştirel çözümlemelerde de erkeğin çocukluktan itibaren sürekli güç ve şiddet ile özdeş biçimde toplumsallaşmasına ve bunun erkekte yol açtığı tahribata göndermeler vardır. R. W. Connell'ın (1998) ifadesiyle tahakkümün araçları iktidar, otorite ve saldırganlık olarak belirir. Ataerkil şiddetin özel yaşamın ve kültürel süreçlerin örgütlenmesine sızan toplumsal güçler oyununda kazanılan toplumsal üstünlük ise, "hegemonik erkeklik" üzerinden okunur. Hegemonya güce dayalı üstünlük anlamina gelmese de, güce dayalı üstünlükle bağdaşmadığı da söylenemez. Şu durumda hegemonik erkeklik ve ataerkil şiddet arasında yakın bir ilişki vardır. Gündelik hayatın olağan rutinine işleyen şiddet dışı, fakat rıza yoluyla kadının tâbi kılınmasına dayalı pratiklerde de, kadına yönelik şiddette somutlaşan baskı ve zorlama türünden iktidar ilişkilerinde de, altta yatan eril tahakküm ve onun hem kadına hem erkeğe dayattığı yasalardır. Tam da buna vurgu yaparcasına filmde Tanrı-Baba'nın Ea'yı bulmak üzere dünyaya gitmesinden sonra Tanrıça-Anne, evde erkeksiz hayatın keyfini sürerken resmedilir. Artık yüzü gülmektedir, sürekli şiddete maruz kaldığı, sessiz ve korku içerisinde geçirdiği günlerden sonra artık evde sevdiği müzikleri dinleyerek, huzur içinde evin işlerini yapmaktadır. Film boyunca zaten hep ev işi yaparken görüntülenmesinde de benzer bir vurgu vardır aslında. Tanrıça-Anne sadece ev işleri yapan, konuşmayan, edilgen bir eş ve anne olarak çizilir. Kadına biçilen geleneksel toplumsal cinsiyet rollerinin bir eleştirisi sunulur filmde. Ea'nın itirazında simgeleşen bir başkaldırı ile üstelik. Ea, İsa Peygamberi kast ederek "Hepiniz ağabeyimi çok iyi tanıyorsunuz ama benim hakkımda bir şey bilmiyorsunuz" sözlerinde kadının ataerkil düzende "ikinci cins" ${ }^{\text {"26 }}$ olarak konumlandırılmasına bir gönderme vardır. Tanrıça dahi olsa, kadının erkeğin mutlak ötekisi olmaktan kurtulamayışı da bundandır.

Tam da bu nedenle Tanrıça, Tanrı'nın ofisine elektrikli süpürge ile girdiğinde, her şey tesadüfen gelişir. Elektrik süpürgesini çalıştırmak için Tanrı'nın dünyayı yönettiği bilgisayarın fişini çeker. İşi bitince tekrar bilgisayarın fişini takar. İşte her şey o zaman değişir. Tanrıça bilgisayarın o zaman farkına varır. Bilgisayar yeniden başladığı zaman. Tanrıçanın yeni bir şifre girerek tekrar başlattığı bilgisayarın ekranında "Merhaba Tanrıça, seni tekrar gördüğüme sevindim" yazısı çıkar. Bu söz, eski toplumlarda rastlandığı varsayılan anaerkil düzene ve çok Tanrılı dinlerdeki Tanrıçalara bir gönderme olarak okunabilir. ${ }^{27}$

26 Bkz. de Beauvoir, S. (1993). İkinci Cins (Çev. B. Onaran). İstanbul: Payel.

27 Sümer Tanrıçası Nammu, Sümer tanrılarının listesini veren bir tablette "Gök'ü ve Yer'i 
Artık dünyanın yönetimi Tanrıça'nın elindedir, yeniden. Sistem yeniden yüklenirken Ea'nın insanlara yolladığı bütün ölüm tarihleri iptal olur. Yeni bir dünya düzenidir söz konusu olan. Tanrıça, "kadınsı" bir dünya kurgular. Gökyüzünün rengini ve desenini kişiselleştirir. Gökyüzü artık mavi değil pembe, mor, sarı renk geçişleri ile ve çiçek desenleri ile bezelidir. Ea başını gökyüzüne doğru kaldırır "Bu annem," der. Annesinin işleri devralmasını mutlulukla karşılar. Haber bülteninde yüzü gülen kadın spiker "Bugün her zaman olduğu gibi yine güzel haberlerimiz var," demektedir. Dünyayı iyilik ve güzellik kaplamıştır. Tanrıça şiddetsiz, savaşsız, kötü haberlere hiç yer olmayan bir dünya yaratır. "Küresel ısınmaya rağmen buzulların erimesi durdu" diye devam eder haber bülteni. Filmin sonlarına yaklaşırken herkese ve filmin tüm karakterlerine bir mutlu son yazılmıştır Tanrıça tarafından. Kadın ve erkek rolleri de

Doğuran Ana" olarak betimlenir (Hooke, 2002, s. 30). Analık hukuku ile yönetilen, ana soylu toplum yapısının ve anaerkil düzenin hâkim olduğu varsayılan eski toplumlara ilişkin temel kaynaklar için Bkz. Bachofen, J. J. (1997). Söylence, Din ve Anaerki (Çev. N. Şarman). İstanbul: Payel. Morgan, L. H. (2015). Eski Toplum (Çev. Ü. Oskay). İstanbul: İnkılap. Ayrıca Bkz. Engels, F. (2010). Ailenin, Devletin ve Özel Mülkiүetin Kökeni (Çev. K. Somer). İstanbul: Sol Yayınları. Engels'in buradaki savlarına yönelik feminist perspektifli bir eleştiri için Bkz. Hartmann, H. (1979). The Unhappy Marriage of Marxism and Feminism: Towards a More Progressive Union. Capital\&Class. 3(2), 1-33. Fatmagül Berktay (2012) tanrıçalar çağından kudretli erkek tanrılara geçişin tarihsel bir izleğini sunar. "Yaratma kudreti"ne ilişkin dinsel açıklamalarda en temel ve biricik evrensel bereket ilkesi olan Ana Tanrıça'dan üretkenliği erkek tanrılar ya da insan-krallar tarafından desteklenen Ana Tanrıça'ya; oradan da önce "ad"da, sonra da yaratıcı "ruh"ta yansıyan simgesel yaratıcılık kavramına geçildiğini ifade eder. Tanrılar panteonunda da tüm güçlere sahip Ana Tanrıça'dan, tüm güçlere sahip Fırtına Tanrısı'na doğru bir geçiş görülür. Burada, Zeus ve Hera çiftinde görüldüğü gibi, artık Ana Tanrıça bereket tanrıçasının evcilleştirilmiş bir versiyonundan ibarettir. Bu adımlardan sonra, sırayı tek ve güçlü erkek tanrı alır. Bu tanrı "yaratma" ilkesinin her iki yönünü de -yoktan var etme ve soyu üretme- kendisinde toplar. Anaerkil toplum varsayımına dair ise Berktay, antropologların itirazlarına işaret eder. Johan Bachofen, Lewis Henry Morgan ve Friedrich Engels gibi erken dönem araştırmacıların yaklaşımlarında anaerkillik ile anasoyluluk ve anayerlilik (matrilocalite) arasında kesin bir ayrım yapılmaması antropologlarca eleştirilmiştir. Berktay'a göre (2012, s. 39) bugün birçok toplum anasoylu ve anayerli olsa bile, bunların hiçbirinde erkekler yerine kadınlar yönetici konumunda değildir. Bu nedenle, birçok antropolog, var olan toplumların hiçbirinin, özellikle ataerkilliğin tam karşıtı biçiminde anaerkil olarak tanımlanamayacağı görüşünde birleşmektedir. Ancak, herhangi bir toplumda soyun ana tarafından hesaplanıyor ve anayerliliğin uygulanıyor olmasının, kadınların rol ve statüleri açısından çok önemli farklılıklar yarattığının da dikkate alınması elzemdir. Kadınların var olan toplumlardaki ikincil statüsünü biyolojiye ve "doğa"ya dayandıran, dolayısıyla bunun ezeli ve ebedi değişmez bir olgu olduğunu öne süren görüşlerin aksine, arkeolojik ve diğer kanitlar, kent devletlerinin ortaya çıkışından önce kadınların konumunun yüksek olduğuna işaret etmektedir (Berktay, 2012, s. 37). 
tersine dönmüştür. ${ }^{28}$ Erkekler hamile kalıyordur artık. Kadınlar ise karnı burnunda kocalarına "bacağını tıraş etmeyi düşünmez misin?" gibi sorular sormaya başlamışlardır. Bu ütopik anlatım, sanki bir yandan kadınlara dayatılan güzellik ideolojisine bir eleştiri iken, bir yandan da, her hâlükârda, yolun sonunun bir cinsin diğer cins üzerinde egemen olmasına doğru gittiğinin mesajını verir gibidir. Mesele iktidar olma meselesidir. Ve gücü kim ele geçirirse kendini ve kendi gibi olanı ayrıcalıklı kılacak bir takım ayrımcılıkları hayata geçirecektir. Tanrıça da kadınlar için daha avantajlı bir dünya kurgular.

Filmin anaerkil dünya tahayyülünde eleştirilecek önemli bir husus, eril tahakküme eleştiri getirirken özcülüğe savrulma riskidir. Filmde şiddetin, savaşların, yıkımların sorumlusu olarak temsil edilen erkekliklere karşı annelik enerjisi ve annelik sevgisi, toplumu bir arada tutan ve dünyayı daha yaşanılır kılan bir güç olarak çizilir. Dünya sorunlarına bu kadınmerkezli bir çözüm vurgusunda bir yanda kadını güçlendiren ve dişil değerleri yücelten bir bakış mevzubahisken bir yandan da meselenin toplumsal ve siyasal temelini göz ardı eden bir biyolojik indirgemecilik söz konusudur.

Her türlü yıkıcılığı ve şiddeti içinde barındıran niteliğine vurgu yaparken erkekliğin doğal/biyolojik ve dolayısıyla değişmez bir özellik olduğunu savunan ve özcülük olarak nitelendirilen bu görüşün temel varsayımına göre annelik ve babalık davranışları biyolojik/genetik kökenlidir $^{29}$ (Sancar, 2011, s. 125). Filmde Tanrıça'nın görevi devralmasından sonra dünyanın sorunsuz, çiçeklerle bezeli bir yere dönüşmesi anlatısında "kadınlar melektir" ya da "kadınlar çiçektir" diyen, bir yanıyla iyi niyetli sözlerin düştüğü yanılgının benzeri söz konusudur. Bu türden, kadını kutsallaştıran yaklaşımlarda kadının tarihsel bir özne oluşu, zaafları ve kusurları ile bir insan olma niteliği rafa kaldırılmış olmaktadır bir yandan. Meselenin bir toplumsal cinsiyet rejimi meselesi olmasından hareket etmek, şu durumda, başka türlü bir toplumsal cinsiyet rejiminin mümkün olduğunu düşünebilmek açısından esas ihtiyaç duyulan hare-

28 Türkiye'den Orhan Kemal'in Tersine Dünya isimli romanı ve bu eserden uyarlanan Tersine Dünүa (Ersin Pertan, 1993) filminde de bu konu işlenir. Bkz. Erus, Z. Ç. (2005). Amerikan ve Türk Sinemalarında Uyarlamalar. İstanbul: Es Yayınları.

29 Yakın zamanda, eril şiddete ve kadınların adeta birer melek olmalarına dair görüş bildiren Micheal Moore'a feminist bir perspektifle sosyal medyadan verilen yanıtlar için bkz. https://www.fempositive.com/michael-moore-gets-brilliantly-shot-woman-trying-prove-women-better-men/ 
ket noktasıdır. Her insanın etik deneyiminde kendini sınırlayan, zorlayan arzuları ve akılsallık biçimleri vardır. Şiddet, tüm canlılarda hayatta kalma refleksi olarak var olan bir potansiyel olarak da okunabilir aynı zamanda. Öte yandan eril şiddet, öğrenilmiş ve benimsetilmiş bir şiddettir. O halde, biyolojik/genetik/hormonal olarak şiddete yatkınlık yerine kültürel-toplumsal ödüllendirmeler/cezalandırmalar yoluyla teşvik edilen bir eril şiddetten söz etmek, özcülüğe savrulma riskini bertaraf edebilecek bir perspektif sunabilir.

Mevcut rejim, kadını ve diğer cinsel kimlik kategorilerini tahakküm altına alırken erkeği de bir ideal olarak sunduğu hegemonik erkeklik kıskacında tutmaktadır. Pierre Bourdieu (2016) Eril Tahakküm'de bir habitus olarak toplumsal cinsiyetin bedenin inanarak, içselleştirerek yaşadığı bir pratik olduğuna işaret eder. Habitus toplumsal cinsiyetin bir yandan içselleştirilirken ve yapısallaşırken bir yandan pratik edildiğini, bir toplumsal pratik olduğunu da görmeyi sağlar. Bu da toplumsal cinsiyet ilişkilerinin değişebileceği anlammna gelir. Normal görünen ve değişmez addedilen toplumsal cinsiyet davranışları, bireylerin farklı toplumsal oyun alanları ve oyuna katılma biçimleri (habitus) arasında meydana gelen uyumsuzluk sonucunda sürdürülemez hale gelir. Benzer bir yoruma Judith Butler'in (2008), toplumsal cinsiyetin performatif olduğu vurgusu üzerinden de varılabilir. Toplumsal cinsiyet rolleri ile kurulan ilişkilerde altüst edici pratiklere ve farklı performanslara her zaman yer vardır. Her ne kadar, filmde çizilen tüm babalar çocuklarına ve eşlerine karşı sevgisiz olsalar da, çocuklarına iyi birer baba ve eşlerine iyi birer hayat arkadaşı olma çabasını elden bırakmayan babalar da vardır. Tıpkı tüm annelerin melek olmayabileceği gibi.

Filmde egemen olan, dişil bir dünyanın şiddetsizliği ve dünyanın anaerkil toplumda kurtuluşu bulacağı kurgusu, bir yanıyla kültürel feminizmin temel savlarını da güçlü biçimde destekler niteliktedir. Kültürel feminist teori, dişil etki ve değerler aracılığıyla yönlendirilen güçlü kadınların toplumuna dair öngörülerde bulunur: Barışseverlik, işbirliği, farklılıkların şiddetsiz biraradalığı, bu toplumun esas özellikleridir. Margaret Fuller'in 1845 tarihli Woman in the Nineteenth Century adlı eseri anaerkil toplum ütopyasının temellerini atar. Fuller, kadınların akıllarını ve güzelliklerini keşfedebildikleri bir toplumda kültürün kadınlaştırılması ile radikal dönüşümler elde edilebileceğini dile getirir. Kadının sezgisel ve düşünsel yeteneği dünyayı iyileştirebilecek güçtedir. Yeter ki kadınların ellerinde böyle bir imkân olsun. Fuller, böyle bir dünyada erkeklerin 
de daha mutlu olacağına inanır (Donovan, 2013, s. 74-81). Bu ütopik görüş, Charlotte Perkins Gilman'ın 1911 tarihli anaerkil ütopyası Herland'de de (Kadınlar Ülkesi) ifade bulur. Gilman, anasoylu panteizm temelli, annelik enerjisinin yönlendirdiği, savaşa, yoksulluğa, cinsiyet temelli iş bölümüne yer olmayan, kadınların özgür olduğu bir toplumsal düzen tasvir eder. ${ }^{30}$ Kadını erkeğe tabi kılan mevcut ataerkil düzenin erkeğe biçtiği tahakküm ve iktidar kurma rolünün erkeğin kişiliğini de zedelediği görüşünde olan Gilman'a göre hem kadın hem erkek için sağlıklı bir toplum, ancak kadının özerkliği ile mümkündür (Lane, 1979, s. 13).

Filmin sonlarına doğru, dişil yasalarla yönetilen dünyada kadınlar daha özgürdür. Tıpkı kültürel feministlerin dile getirdiği gibi, kadınların özgür olduğu bir toplumda herkes özgürdür. Ea film boyunca altı havarisini aramış ve bulmuştur. Altı havarisinin de ortak yönleri mutsuz olmalarıdır. Mutsuzluklarının temel nedeni ise özgür olamamalarıdır. Altı havari mutsuz evlilik, aşksızlık, yalnızlık ve toplumsal normların dışında olmak gibi nedenlerle, yaşadıkları hayatların çeperine ötelenmiş, dışarıda kalmış insanlardır. Anaerkil dünyada herkes muradına erer. Herkes aradığını bulur. Örneğin iş adamı kocasının ilgisizliği ile tüm hayat enerjisini kaybeden Martine aradığı aşkı, bir sirkten satın alıp kurtardığı gorilde bulur. Bir çocukları olur ve hep mutlu yaşarlar. Burada, inceden bir, türcülük ve insanmerkezcilik (antroposantrizm) eleştirisi sezilir. Bir diğer havari Willy, oğlan çocuğu olarak dünyaya gelse de bir kız çocuğu gibi yaşamak ister. Yeni dünya onu da bağrına basar. Artık elbise giyerek ve mutluluk dansları ederek yaşar. Cinselliğe, cinsiyete ve aşka sınır koymayan huzurlu yeni dünyada herkesin ruhu ve bedeni özgür olur. Tanrıça dünyayı yönetmekle meşgulken, Tanrı-Baba ise dünyevi hayatı yaşar ve Ea'yı bulma macerası içerisinde zorluklarla mücadele ederek günlerini geçirmeye devam eder.

\section{Sonuç}

The Brand New Testament 21. yüzyll modern toplumunda din, evlilik ve ataerkil aile kurumunun yaşadığı değişim ve dönüşümün bir alegorisini

30 Filmin anaerkil dünya kurgusu feminist ütopya yazınını da çağrıştırır. Gilman'ın da dahil olduğu, Margaret Atwood, Marge Piercy gibi feminist ütopya edebiyatının önde gelen yazarları, eserleri ile feminist ideallerle yeniden inşa edilen toplumların ütopik hikâyelerini anlatmışlardır. Fransız ve Amerikan edebiyatında feminist ütopyalara dair bir çalışma için Bkz. Bartkowski, F. (1989). Feminist Utopias. Lincoln: University of Nebraska Press. 
sunar. Dinsel komedi filmlerinde aşina olunan, dini figürleri alaya alırken geleneksel toplumsal kurumların yerini sağlamlaştıran, hayatı dini merkeze alarak yorumlayan perspektif yerini, güçlü biçimde, geleneksel kurumların aşındırıldığı bir anlatıya bırakmıştır. Bir yandan film, kadınlar ve çocuklar üzerindeki erkek hâkimiyetinin ortadan kalktığı dünya kurgusu ile bir ütopya anlatısıdır. Bu ütopyada özgür aşk, hayatın temelidir. Söz konusu özgür aşkta türcülüğe ve insan merkezciliğe dahi yer yoktur. İnsan ve insan olmayan diğer canlılar arasında da aşk mümkündür. Hamileliği bizzat deneyimleyen, bebeklerini karınlarında taşıyan babalar bu dünya kurgusunda, evlatları ile bambaşka bir duygusal bağ geliştirebilirler.

Filmde, ataerkil düzenle yönetilen "eski dünya"da sadece kadınlar değil erkekler, çocuklar, içine doğduğu bedenin çizdiği sınıra itirazı olanlar ve hayvanlar da mutsuzdur, baskı altındadır. Film, anaerkil bir dünyada bu baskıların üstesinden gelinmesini Tanrı-Baba'nın yanlışlarını vurgulayarak ve ona baş kaldıran evlatlarının haklllığına gönderme yaparak hikâyeleştirir. Tanrı'yı bu derece eleştirel bir mizah bağlamına yerleştirmesi, filmi oldukça cesur bir dinsel komedi örneği yapar. Diğer yandan, yaratılışa dair çizdiği hikâye ve Tanrı'nın tek bir dokunuşla bütün hayatı belirleme gücüne yaptığı vurgu ile inanç merkezli bir anlatım sunar.

Eril değerlerin yerini dişil değerlere bıraktığı bir yaşamı kurgulayan film sömürünün olmadığı, barışçı bir dünya özlemini dile getirir. Bunun için de kadının özgürleşmesinin ve güçlenmesinin en önemli çıkış noktası olduğuna işaret eder. Tam da bu nedenle kadın peygamber Ea ve Tanrıça annesi filmin merkezindedir. Her ne kadar, "kadın eli değen her şey güzelleşir" dercesine Tanrıça yönetimindeki dünyayı idealize etse ve özcülüğe savrulma riski ile karşı karşıya olsa da film, tüm cinsel kimliklerin ve doğadaki tüm canlı varlıkların özgürleşmesini talep eder. $\mathrm{Bu}$ yönüyle film, dinsel komedinin politik sinemada önemli bir imkân olduğunu gözler önüne sürer.

Sinema ve din ilişkisine ve kutsal dini figürlerin mizah unsuru yapılmasının sinemada nasıl yer bulduğuna dair tartışmalardan yola çıkarak bu çalışma, feminist film eleştirisini komedi türü özelinde, dinsel temalı bir filme uygulamıştır. Film çalışmaları alanında dinsel komedinin, özellikle de Tanrı'nın komedide temsili konusunun ulusal ve uluslararası düzeyde oldukça sınırlı çalışıldığı göz önünde bulundurulduğunda, nihayetinde, bu çalışmanın yeni araştırmalar için bir kapı aralaması ümit edilmektedir. 


\section{Kaynakça}

Acar-Savran, G. (2004). Beden Emek Tarih. İstanbul: Kanat.

Ali, W. (2001). From the Literal to the Spiritual: The Development of the Prophet Muhammad's Portrayal from 13th Century Ilkhanid Miniatures to 17th Century Ottoman Art. EJOS, 4(7), 1-24.

Anker, R. (2004). Catching Light: Looking for God in the Movies. MI: William B. Eerdmans Publishing.

Arendt, H. (2012). Şiddet Üzerine (Çev. Bülent Peker). İstanbul: İletişim.

Berger, P. L. (2014). Redeeming Laughter: The Comic Dimension of the Human Experience. Berlin/New York: Walter de Gruyter.

Berktay, F. (2012). Tektanrılı Dinler Karşısında Kadın. İstanbul: Metis. Bourdieu, P. (2016). Eril Tahakküm (Çev. B. Yllmaz). İstanbul: Bağlam. Boespflug, François (2011). Laughing at God: The Pictorial History of Boundaries Not To Be Crossed. H. Geybels \& W. Van Heck (Eds.). Humor and Religion (s. 204-218). London: Continuum.

Butler, J. (2008). Cinsiyet Belası: Feminizm ve Kimliğin Altüst Edilmesi (Çev. B. Ertür). İstanbul: Metis

Connell, R. W. (1998). Toplumsal Cinsiyet ve İktidar (Çev. C. Soydemir). İstanbul: Ayrıntı.

Çaylı Rahte, E. (2015). Kadına Yönelik Şiddetin Medya Halleri: İktidarın Dili, Acının İkonografisi ve Estetize Edilmiş Şiddet Üzerine. D. Güler Aydın (Der.) Kadına Yönelik Şiddetin Ekonomi Politiği (s. 51-71). Ankara: Hacettepe Üniversitesi Yayınları.

Çolak, E. (2016) İslam İle Görsel Mizah: Türkiye'de İslami Mizah Dergiciliğinin Dönüşümü. Moment Dergi, 3(1), 228-247.

Donovan, J. (2013). Feminist Teori (Çev. A. Bora vd.). İstanbul: İletişim. Freud, S. (1998). Totemve Tabu (Çev. N. Berkes). İstanbul: Cumhuriyet.

Geybels, H \& Van Heck, W. (2011). Humor and Religion. London: Continuum.

Hamilton, W. (1959). Humor: Plausible and Demonic. The Christian Century, 76, 807.

Hyers, M. C. (1968) The Dialectic Of The Sacred And The Comic. Cross Currents, 19(1), 69-79. 
Hooke, S. H. (2002). Ortadoğu Mitolojisi (Çev. A. Şenel). Ankara: İmge. Karatekin, D. (2016). Medya Tanitım: Yeni Ahit. Folklor/Edebiyat, $22(88), 283-285$.

Lamm, R. (1991) 'Can We Laugh at God?': Apocalyptic Comedy in Film. Journal of Popular Film and Television, 19(2), 81-90.

Lane, A. J. (1979). Introduction. Herland. Gilman, C. P. New York: Pantheon Books.

Laslett, P. (1949). Patriarcha and the Other Political Works of Sir Robert Filmer. Oxford: Blackwell.

Lippitt, J. (2005). Is a Sense of Humour a Virtue? The Monist, 88(1), 72-92.

Maktav, H. (2010). Sinema ya da İlahi Aşk: İslami Sinemada Tasavvufi Yolculuklar. sinecine 1(2), 31-55.

Mazur E. M. (2011). Encyclopedia of Religion and Film. Encyclopedia of Religion and Film. California: ABC-CLIO.

McIntyre, E. (2013). God's Comics: Religious Humour in Contemporary Evangelical Christian and Mormon Comedy. (Yayımlanmamış Doktora Tezi). University of Sydney, School of Letters, Arts and Media, Sydney.

Morreall, J. (1999). ComedY, Tragedy, and Religion. NY: State University of New York Press.

Oskay, Ü. (2000). Kitle İletişiminin Kültürel İşlevleri. İstanbul: Der.

Sancar, S. (2011). Erkeklik: İmkansız İktidar. İstanbul: Metis.

Saroglou, V. (2002). Religion and Sense of Humor: An A Priori Incompatibility? Theoretical Considerations from a Psychological Perspective. Humor, 15(2), 191- 214.

Stanton, E. C. (1898). Woman's Bible. (e-book) https://archive.org/ stream/thewomansbibleog88ogut/wbiblio.txt (Erişim tarihi: 4 Nisan 2018)

Şimşek, G. (2016). Sinemada Korku ve Din. İstanbul: Pales.

Thompson, P. (1994). Comedy and Christianity: Surveying the Ground. Christianity and Literature, 44(1), 59-72.

Thoma, D. (2011). Babalar: Modern Bir Kahramanlık Hikayesi (Çev. F. Doğan). İstanbul: İletişim.

Türkel, E. ve Kasap, F. (2014). "Türk Sineması'nda Korku: 2000 
Sonrası Türk Korku Sineması'nda Dinsel Motifler Üzerine Bir İnceleme Ve Yaratım Sorunları". Journal of International Social Research. 7 (32), 711-721.

Toprak, B. (2015). Kertenkele'nin Serencamı: Bir Film Üç Algı. Kolektif, Sinema ve Din (s. 542-544). İstanbul: DEM.

Ünal, A. (2015). Uyumlu Bir Dünya İnşası Bağlamında Sinema ve Din İlişkisi: 'Life of $\mathrm{Pi}^{\prime}$ Örneği . International Journal of Science, Culture and Sport, 12, 567-583.

Van Dormael, J (Yönetmen). (2015). The Brand New Testament. [Film]. Belçika: Terra Incognita Films.

Walby, S. (2016). Patriyarka Kuramı (Çev. H. Osmanağaoğlu). Ankara. Dipnot.

Williams, P. (2000). Religion Goes to the Movies. Religion and American Culture: A Journal of Interpretation, 10(2), 225-239.

Wright, M. J. (2007). Religion and Film: An Introduction. London: I.B. Taurus.

Yaylagül, L. (2012). 2000'ler Türkiyesi'nde Sinema ve Din: Takva Filmi Örneği. İletişim Kuram ve Araştırma Dergisi, Bahar, 42-65.

Yenen, İ. (2011). Toplumsal Tezahürleri Bağlamında Türk Sinemasında Din, Dindarlık ve Din Adamı Olgusu. (Yayınlanmamış Doktora Tezi). Ankara Üniversitesi Sosyal Bilimler Enstitüsü, Ankara.

Yorulmaz, B. (2016). Popüler Filmlerde Din. İstanbul: İstanbul Tasarım.

Yorulmaz, B. (2015). Sinema ve Din Eğitimi. İstanbul: Dem.

Zwick, R. (2017). The Presence and Hiddenness of God in Noah. R. Burnette-Bletsch \& J. Morgan (Eds.), Noah as Antihero: Darren Aronofsky's Cinematic Deluge (s.134-145). NY: Routledge. 
